\title{
Mine Slope Stability Based on Fusion Technology of InSAR Monitoring and Numerical Simulation
}

\author{
Liwei Yuan $\mathbb{D}^{1,2}$ Chenyang Li $\mathbb{D}^{1,},{ }^{1}$ Sumin Li $\mathbb{D},{ }^{3}$ Xiangsong Ma $\mathbb{D}^{4},{ }^{4}$ Wei Zhang $\mathbb{D}^{5}$ \\ Darong Liu $\mathbb{D},{ }^{6}$ Guangjin Wang $\mathbb{D}^{3},{ }^{3}$ Feihong Chen $\mathbb{D}^{7},{ }^{7}$ and Xiaojian Hou $\mathbb{D}^{7}$ \\ ${ }^{1}$ College of Public Security and Emergency Management, Kunming University of Science and Technology, Kunming 650093, \\ Yunnan, China \\ ${ }^{2}$ Key Laboratory of Geological Disaster Risk Prevention and Control and Emergency Disaster \\ Reduction of Ministry of Emergency Management of the People's Republic of China, Kunming 650093, Yunnan, China \\ ${ }^{3}$ College of Land and Resources Engineering, Kunming University of Science and Technology, Kunming 650093, Yunnan, China \\ ${ }^{4}$ Kunming Engineering \& Institute of Nonferrous Metallurgy Co., Ltd., Kunming 650093, Yunnan, China \\ ${ }^{5}$ Yuxi Dahongshan Mining Co., Ltd., Yuxi, Yunnan, China \\ ${ }^{6}$ Yunnan Gold Mining Group Co., Ltd., Kunming, China \\ ${ }^{7}$ Kunming University of Science and Technology Design and Research Institute, Kunming, Yunnan, China
}

Correspondence should be addressed to Sumin Li; lism@kust.edu.cn

Received 5 November 2021; Revised 24 November 2021; Accepted 9 December 2021; Published 25 January 2022

Academic Editor: M Pallikonda Rajasekaran

Copyright (C) 2022 Liwei Yuan et al. This is an open access article distributed under the Creative Commons Attribution License, which permits unrestricted use, distribution, and reproduction in any medium, provided the original work is properly cited.

In this paper, the slope of the open pit of Dahongshan iron ore mine in Yunnan is taken as the research object, the safety coefficient and settlement values of the slope under natural and rainfall conditions are derived by the finite element software Midas/GTS, and the surface settlement versus time is produced by fusing the InSAR monitoring results of the study area for a whole year to judge the stability of the open pit slope. The results show that the settlement and deformation areas shown by numerical simulation and InSAR monitoring results are consistent; the comparison between InSAR monitoring results and rainfall intensity shows that the cumulative value of slope settlement has a high correlation with heavy rainfall. The safety coefficients of the slopes of the open pit under natural conditions and rainfall conditions are 1.50 and 1.21, the cumulative value of settlement in InSAR monitoring data for one year is $18.4 \mathrm{~mm}$, and no obvious large deformation area is found. The use of numerical simulation combined with InSAR monitoring can realize the analysis of the stability of the slope of the open pit mine.

\section{Introduction}

The use of numerical simulations fused with monitoring techniques has been the main research method for open pit slope stability analysis. The slope of the open pit mine is accompanied by the open pit mine from the beginning to the end, the depth of the open pit mine increases further, the height of its slope also increases further, and the risk of landslides and other instability is also increasing year by year [1-4]. As the instability of open pit slopes can endanger the lives of workers and cause property damage, it is of practical importance to study the stability of open pit slopes. In order to ensure that open pit mining can be carried out safely and smoothly, the prediction and analysis of the stability of the open slope of the mining site is becoming more and more important. With the rapid development of computer science, numerical simulation analysis has become the main tool to study these kinds of engineering problems [5-11]. Software that fuses strength theory and numerical simulation can quickly and effectively simulate changes in slope stresses. Huang et al. [12] simulated the effect of vibration on slope stability by means of numerical simulation. Chen et al. [13] analyzed the stability of very large open pit slopes by using FLAC3D software to provide important guidance for the design, optimization, and construction of such open pit mines. Yu [14] used ABAQUS numerical simulation 
software to analyze the stability of slopes in open pit mines under rainfall infiltration conditions, and the results showed that the damage patterns of different slope ratios under surface rainfall infiltration conditions also differed significantly. Dong and Guo [15] used Midas/GTS NX numerical simulation software to study the characteristics of dynamic instability response of gently inclined open-air slopes under earthquake action. The results of the study can provide guidance for slope strengthening and protection under earthquake loads. Srikrishnan et al. [16] conducted numerical simulations using SLOPE/W and FLAC3D software programs to analyze the effects of earthquakes on the slopes of open pit mines. Liu et al. [17] used Fushun West Open Pit Mine as the research background and analyzed the stability of open pit slopes under the action of both rainfall and earthquake using GeoStudio numerical simulation software. Using the Victorian brown coal open pit slope as a background, Zhao and You [18] used the FEM to demonstrate that rainfall is an important cause of slope instability in open pit mines. The results of surface rainfall and mine earthquake have great influence on the safety of slopes and should be reinforced in advance. The reliability of a single numerical simulation for slope stability analysis is insufficient because the results obtained from numerical simulation are too ideal [19], and the combination of field monitoring data with numerical simulation can predict the stability of slopes in open pit mines in a more scientific and reliable way. He and $\mathrm{Li}$ [20] analyzed the stability of an open slope of a phosphate mine using a combination of numerical simulation software and on-site placement of monitoring points. Yang and Hou [21] used the SEEP/W finite element software to simulate the whole process of the change of the seepage field of the rock body of the slope under the infiltration condition of heavy rainstorm and found that the landslide generally has a lag of about $24 \mathrm{~h}$ after the heavy rainstorm after using the slope sliding monitoring system and the real-time monitoring system of rainfall. Taking Fushun as an object of study, Zhang et al. $[22,23]$ used monitoring and numerical simulation methods to accurately circle the sliding surface of the slope. Sertabipoğlu et al. [24] combined monitoring data and finite element (FE) methods to propose a dynamic method that can predict the risk of slope damage in the field. Li et al. [25] conducted a numerical analysis using monitoring and FEMLIP to determine the mechanism of rock sliding, which can be used as an aid for future disaster prediction. López-Vinielles et al. [26] used remote sensing data and geomechanical modeling as a case study to remotely analyze slope instability in open pit mining areas in Las Cruces, Spain.

A large number of scholars used numerical simulation methods combined with monitoring to conduct research on the stability of open pit slopes and used conventional GNSS, total station monitoring $[27,28]$, etc. There are few applications for InSAR (synthetic aperture radar jamming) obtaining mine surface deformation data but which is developing more rapidly today in other fields [29-31]. Compared to conventional monitoring methods, InSAR technology can monitor large areas and long periods of time with very little manual effort. This paper takes the slope of Dahongshan iron ore open pit mine as the engineering background, uses numerical simulation to study the stability of the slope under natural and rainfall conditions, and selects suitable monitoring points to comprehensively analyze the stability of the slope by InSAR satellite monitoring data. The results are more scientific and reliable. It can provide reference for the subsequent mining and slope management of Dahongshan open pit iron ore mine.

\section{Project Background and Analysis Method}

2.1. Project Background. The climate type of Dahongshan open pit mine is subtropical. It is characterized by clear dry and wet seasons and abundant rainfall. The annual rainfall in this area is $700-1200 \mathrm{~mm}$, with an average rainfall of $930.8 \mathrm{~mm}$. More than $60 \%$ of the rainfall is concentrated from June to September. The study area is located in area I of the slope of the quarry, the lowest elevation of its mining status is $880 \mathrm{~m}$, the highest elevation is $1150 \mathrm{~m}$, the vertical height is $270 \mathrm{~m}$, the overall slope angle of the slope of the open pit is about $39^{\circ}$, and the status of the slope of the open pit is shown in Figure 1.

The physical and mechanical parameters of the stratigraphic rock in the area were obtained by sampling in the field and conducting indoor rock mechanics tests as shown in Table 1.

\subsection{Principles of Numerical Simulation of Slopes}

2.2.1. Strength Discounting Method. Some traditional slope stability analysis methods are based on limit equilibrium theory, which has its limitations. It does not consider the internal stress-strain relationship of geotechnical body; it cannot analyze the occurrence and development process of slope damage; it cannot consider the influence of deformation on slope stability; it does not consider the joint action of geotechnical body and supporting structure and their deformation coordination relationship; and it does not take into account the joint action of geotechnical body and support structure and their deformation coordination relationship. Because it makes many artificial assumptions in the analysis and calculation, it does not match with the actual geotechnical body in the state. The finite element strength reduction method not only takes into account the aforementioned defects of the traditional limit equilibrium theory but also does not need to assume the shape and location of the sliding surface in advance and does not need to carry out strip division, but combines with the automatic search of sliding surface by finite element analysis software, and the safety factor is obtained.

In calculating the minimum safety factor, the strength discounting method considers the elastic modulus $E$ and Poisson's ratio $v$ of the slope to be constant, and the cohesion and internal friction angle are discounted in the following way until the calculation dissipates, and the $F s$ at the time of dissipation is taken as the minimum safety factor. For shear damaged slopes, the factor of safety equation for damage is as follows: 

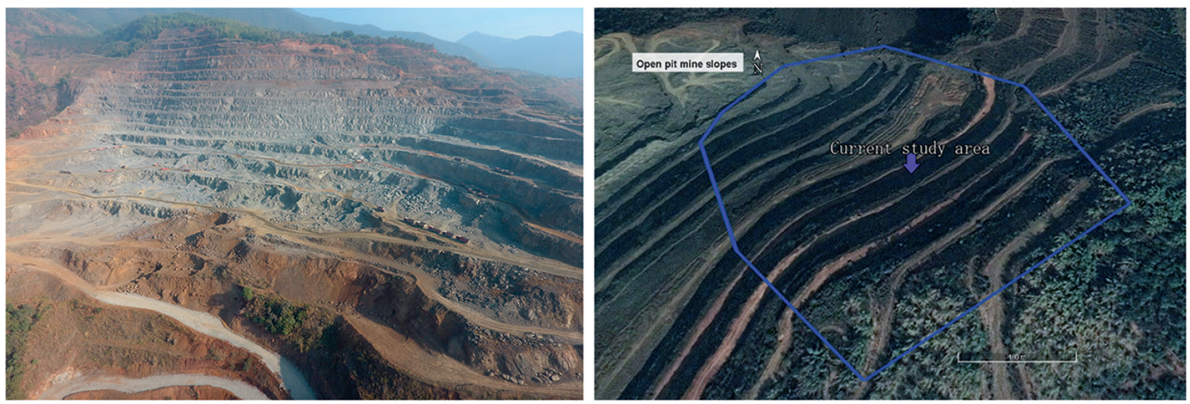

FIgURE 1: Status of Dahongshan open pit mine slope.

TABLE 1: Mechanical parameters of rock mass.

\begin{tabular}{|c|c|c|c|c|c|}
\hline Rock-solid name & $\begin{array}{l}\text { Weight capacity (kN/ } \\
\left.\mathrm{m}^{3}\right)\end{array}$ & $\begin{array}{l}\text { Modulus of elasticity (kN/ } \\
\left.\mathrm{m}^{2}\right)\end{array}$ & $\begin{array}{l}\text { Cohesion } \\
(\mathrm{MPa})\end{array}$ & $\begin{array}{l}\text { Angle of internal } \\
\text { friction }\end{array}$ & $\begin{array}{l}\text { Poisson's } \\
\text { ratio }\end{array}$ \\
\hline Shale sandstone & 26.46 & 40000000 & 146 & 34 & 0.22 \\
\hline $\begin{array}{l}\text { Dark green hornblende sodium } \\
\text { lava }\end{array}$ & 27.44 & 71000000 & 333 & 32 & 0.25 \\
\hline $\begin{array}{l}\text { Garnet green mud hornblende } \\
\text { schist }\end{array}$ & 29.008 & 46000000 & 147 & 32 & 0.19 \\
\hline $\begin{array}{l}\text { Gray-green hornblende sodium } \\
\text { lava }\end{array}$ & 28.616 & 28000000 & 105 & 26 & 0.28 \\
\hline
\end{tabular}

$$
\begin{aligned}
& C^{\prime}=\frac{C}{F_{S}} \\
& \varphi^{\prime}=\operatorname{acr} \tan \left(\frac{(\tan \varphi)}{F_{S}}\right),
\end{aligned}
$$

where $C, C^{\prime}$ represent the cohesion of soil before and after discounting; $\varphi, \varphi^{\prime}$ represent the angle of internal friction of soil before and after discounting; and $F_{S}$ is the discounting factor.

The yield criterion is chosen from the Mohr-Coulomb strength theory, and the expression is

$$
\tau=C+\sigma \tan \varphi,
$$

where $\sigma$ and $\tau$ are the positive and tangential stresses on the slip plane, respectively. The Mohr-Coulomb strength condition shows that when a point in the material slips (shears) in a certain plane, the tangential stress $\tau$ acting on the plane needs to overcome the frictional force formed due to the positive stress $\sigma$ acting on the surface in addition to the cohesive force $c$ inherent in the material.

2.2.2. Convergence Criterion and Assumptions. The strength reduction method is an iterative calculation process to find the slope stability coefficient; therefore, it is necessary to choose the appropriate convergence criteria to determine whether the calculation converges. Midas/GTS software was selected for this simulation, and the software convergence criterion uses displacement, internal force, and energy as the standard convergence conditions. The internal force convergence was chosen with a convergence accuracy of 0.001 .
2.2.3. Numerical Simulation. Based on the results of the site exploration and the geological exploration report of the study area, the most representative geological profile with high risk is selected to establish the geological generalization model, and the corresponding monitoring points are selected. The stratigraphy is divided into four layers: (1) shale sandstone; (2) dark green hornblende sodium lava; (3) garnet green mud hornblende schist; and (4) gray-green hornblende sodium lava. The monitoring points were selected as follows (Figure 2).

Using Midas/GTS software, a 1:1 2D numerical model with the actual open pit slope is established and the model is meshed. To make the simulation results more accurate, the following approaches to modeling are available. The foot of the modeled slope is 1.5 times the slope height from the side boundary of the model, the top of the slope to the side boundary of the model is 2.5 times the slope height, and the top and bottom boundaries of the model are 2 times the slope height. The final numerical analysis model is established with the length of $1080 \mathrm{~m}$ in $X$-axis direction and $540 \mathrm{~m}$ in $Y$-axis direction, the model boundary is constrained by displacement, all nodes at the bottom of the model are constrained by $X$ and $Y$ directions, and the left and right sides of the model are constrained by $X$ direction. The model slope is free boundary. It is assumed that no nodal fractures are considered. There are 4493 grid cell nodes and 4356 cells in the model. The numerical model and grid division are shown in Figure 3.

\section{Analysis and Discussion of the Results}

3.1. Analysis of Numerical Simulation Results. The slope type of Dahongshan open pit mine is grade II. The safety factor of the slope under self weight load is not less than 1.15 , and the safety factor of the slope under rainfall is not less than 1.13. 


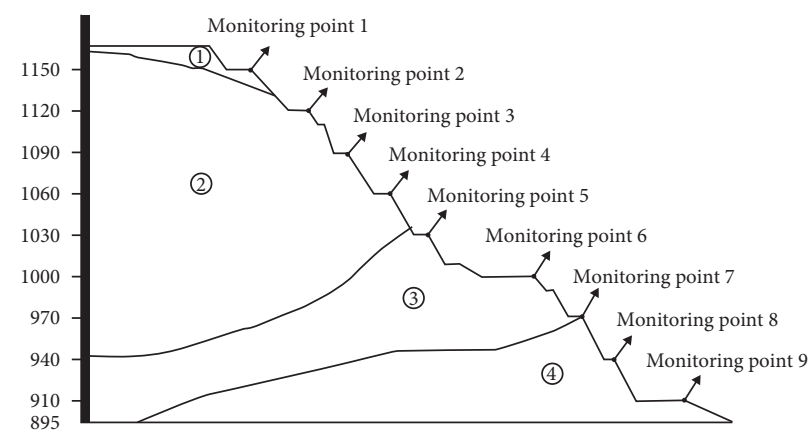

FIGURE 2: Geological generalization and monitoring point arrangement.

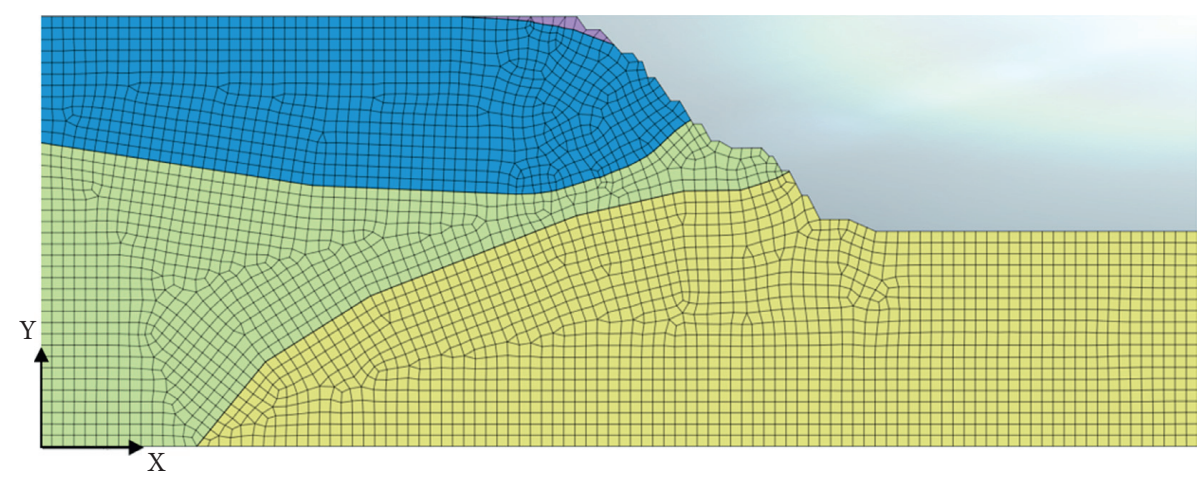

Figure 3: Grid division.

3.1.1. Natural Conditions. Only under the gravity load, the calculated slope safety factor is 1.50 , which is greater than the standard requirement of 1.15 , and the slope is in a stable state under the natural working condition. The maximum displacement in the $X$ direction occurs at the upper slope of the open pit slope 910 platform (Figure 4), and the maximum displacement value is $0.062 \mathrm{~m}$. There is no obvious shear stress concentration zone on the slope in the natural state, and the plastic zone can be seen from the garnet green mud hornblende schist layer to the graygreen hornblende metamorphic rock lava layer by the plastic deformation diagram (Figure 5), and the plastic zone has the tendency of local penetration. The plastic deformation is mainly concentrated at the slope corner of platform 910, the plastic zone is mainly concentrated near platform 910 and platform 890, and other plastic zones are distributed before platforms 970 to 1030 . From the figure, it can be seen that there is no possibility of overall landslide of the slope but only the possibility of local landslide, and the location of local landslide is from platform 1030 to platform 895 .

3.1.2. Rainfall Conditions. According to the weather and hydrological data of the study area, we simulated the infiltration of rainfall on the slope under the rainy season conditions. Based on the average monthly rainfall of the Dahongshan open pit in the past years and the statistics of the monthly rainfall days in the Dahongshan area in the past 20 years, we chose to simulate continuous rainfall with a rainfall of $200 \mathrm{~mm} / \mathrm{d}$ and a duration of 2 days.
From the results, the safety factor of the slope under the rainfall condition is 1.21 , which is higher than the requirement of the code, and the slope is in a stable condition. The maximum value of the displacement in $X$ direction appears at platform 910 (Figure 6), and its maximum value is $0.074 \mathrm{~m}$. By observing the distribution of the plastic zone (Figure 7), it can be seen that the rainfall has a significant influence on the stability of the slope. Compared with the natural condition, the range of plastic zone of the slope increases under the rainfall condition. The plastic zone extends from platform 1030 to the upper part of the overall slope. The plastic deformation zone extends from the garnet green mud hornblende schist layer to the dark green hornblende meta-sodic lava and has a tendency to increase upward. It is also obvious that the plastic zone is developing rapidly at the 910 foot platform, and the rainfall has a significant impact on the 910 and 895 platforms.

\subsection{Analysis of InSAR Monitoring Results}

3.2.1. Feasibility Analysis of InSAR Monitoring Results. According to the numerical simulation results, four monitoring points $6,7,8$, and 9 were selected at the locations with greater influence on the slope, and the elevation values of the selected points from January 1, 2019, to March 31, 2019, were recorded using a total station with conventional monitoring means (Table 2), and the elevation value on January 1, 2019, was taken as the cumulative reference starting time for settlement, and the recording period was once a month. The 


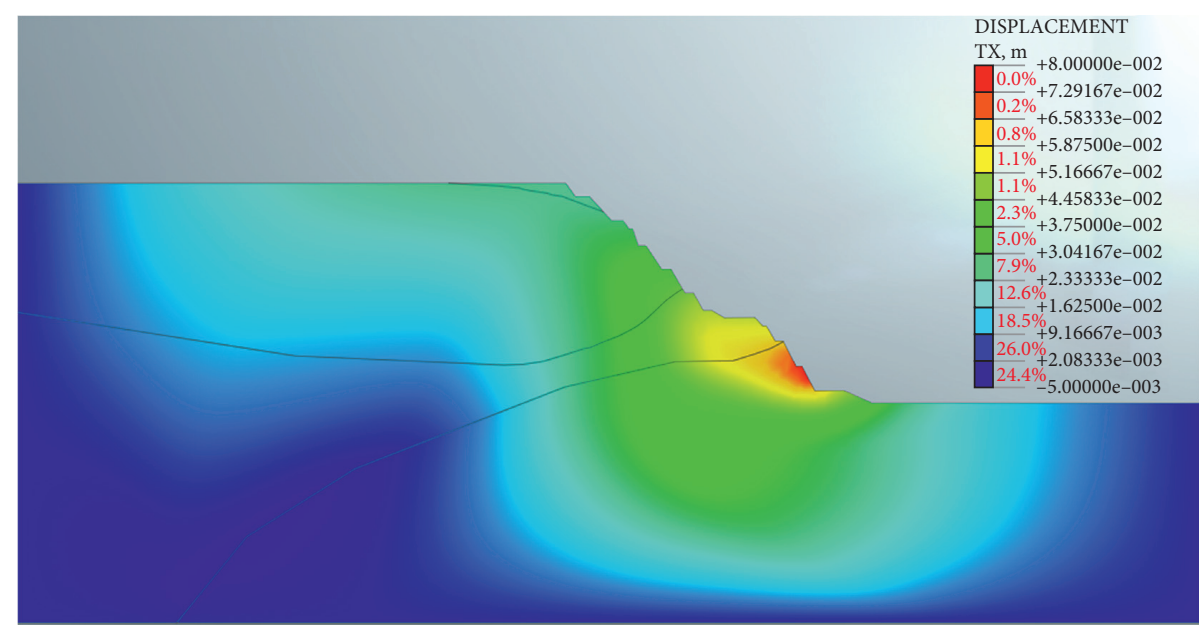

FIGURE 4: $X$-direction displacement diagram under natural working condition.

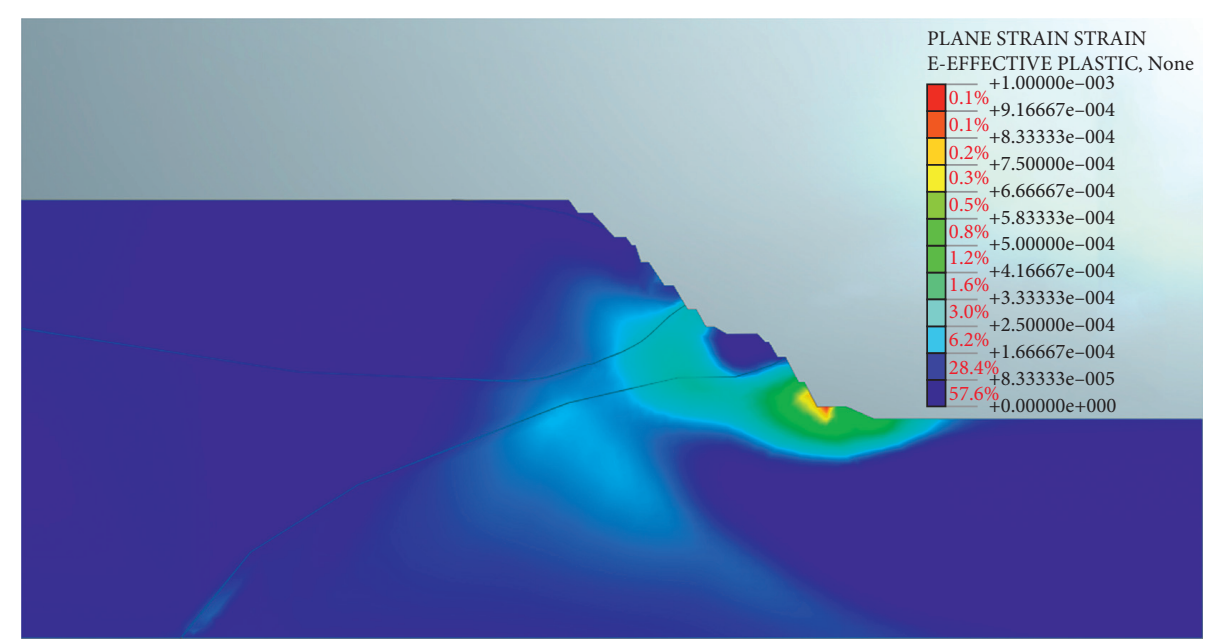

FIGURE 5: Distribution of plastic zone of natural working condition slope.

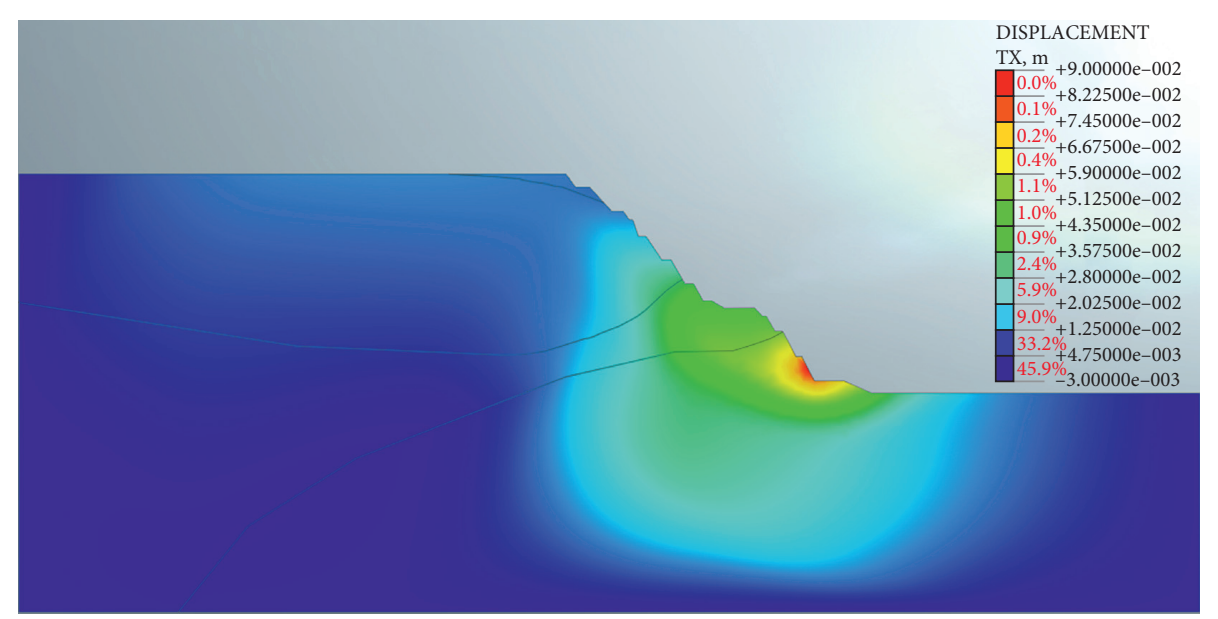

Figure 6: $X$-direction displacement diagram under rainfall conditions.

feasibility of InSAR monitoring was determined by producing a graph of the amount of change in elevation at the four points compared to the amount of change in surface settlement values monitored by InSAR.
From the results of the four monitoring points in the graph comparing the amount of settlement variation monitored by the total station and InSAR (Figure 8), the surface settlement values derived from InSAR monitoring 


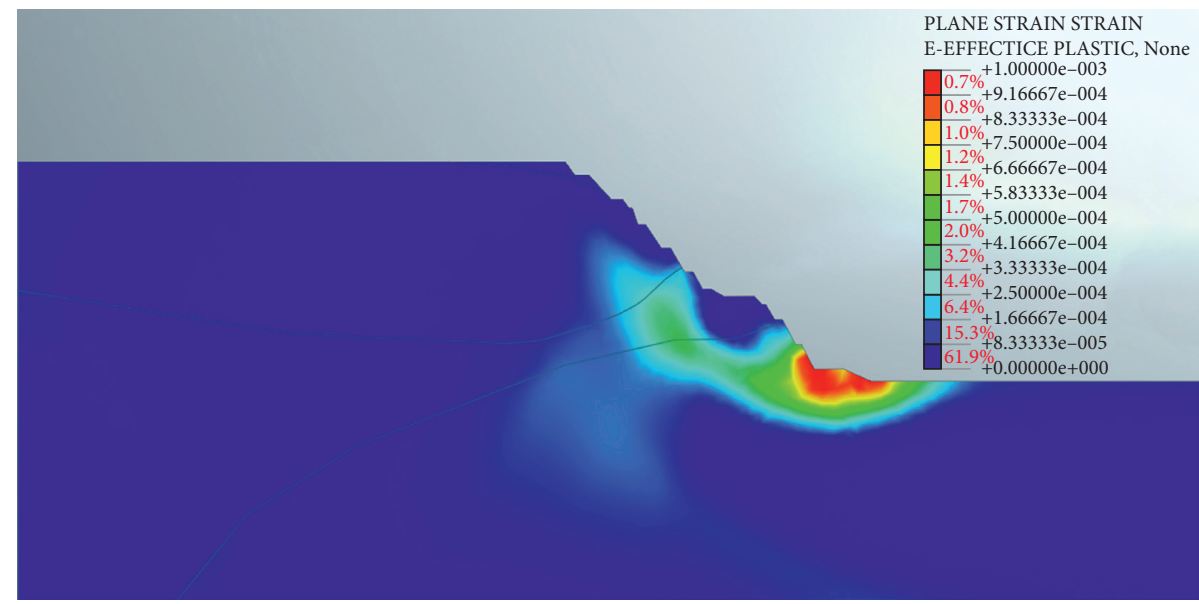

Figure 7: Distribution of plastic zone of side slope under rainfall conditions.

TABLE 2: Total station monitoring data record.

\begin{tabular}{lcccc}
\hline $\begin{array}{l}\text { Monitoring } \\
\text { point }\end{array}$ & $\begin{array}{c}\text { January 4, 2019, elevation } \\
\text { value }(\mathrm{m})\end{array}$ & $\begin{array}{c}\text { January } 31,2019, \text { elevation } \\
\text { value }(\mathrm{m})\end{array}$ & $\begin{array}{c}\text { February 28, 2019, elevation } \\
\text { value }(\mathrm{m})\end{array}$ & $\begin{array}{c}\text { March 31, 2019, elevation } \\
\text { value }(\mathrm{m})\end{array}$ \\
\hline $\begin{array}{l}\text { Monitoring } \\
\text { point 6 }\end{array}$ & 971.8791 & 971.8785 & 971.8781 & 971.8775 \\
$\begin{array}{l}\text { Monitoring } \\
\text { point 7 }\end{array}$ & 942.2641 & 942.2634 & 942.2632 & 942.2626 \\
$\begin{array}{l}\text { Monitoring } \\
\text { point 8 }\end{array}$ & 911.8373 & 911.8367 & 911.8365 & 911.8355 \\
$\begin{array}{l}\text { Monitoring } \\
\text { point 9 }\end{array}$ & 894.8471 & 894.8464 & 894.8463 & 894.8457 \\
\hline
\end{tabular}

are generally higher compared to the monitoring data from the total station, but the difference in their variation values is not significant. The largest difference in the amount of settlement change between the two monitoring methods occurs at monitoring point 8 during the time period from January 4 to January 31,2019 , with a difference of $0.4 \mathrm{~mm}$. The difference value between the points during the rest of the time periods does not exceed $3 \mathrm{~mm}$, and even the settlement values derived from the two monitoring methods at monitoring point 6 during the change time period from February 1, 2019, to February 28, 2019, are in complete agreement. From the data, it can be seen that InSAR monitoring can achieve the effect of conventional monitoring on surface deformation monitoring.

3.2.2. Slope Stability Based on InSAR Monitoring. On-site monitoring data within the study area were obtained through InSAR monitoring from 4 January 2019 until 30 December 2019, with a monitoring data acquisition period of 12 days/time and a total of 29 sets of valid monitoring data obtained during the time period. The 29 sets of data were used to produce a monitoring settlement colour chart, from which the settlement of the 2019 open pit slopes can be seen (Figure 9). It can be seen from the settlement colour chart that monitoring points $6,7,8$, and 9 had greater settlement compared to the other monitoring points over the course of the year 2019, with the settlement areas mainly located on the quarry slopes from platform 895 to platform 1030. The settlement of the upper part of the slope is insignificant with the accumulated settlement values at monitoring points 1, 2, 3 , 4, and 5 all remaining within $10 \mathrm{~mm}$. The numerical modeling of the open pit slopes is consistent with the field monitoring results as can be seen from the monitored settlement colour chart and the numerical simulation results in the previous section. Its settlement position remains consistent, with significant settlement in the lower half of the overall slope (platforms 895-1030), and the lower half of the open pit slopes is high-risk area for landslide hazards.

3.2.3. Comparison between Monitored Settlement and $\mathrm{Nu}$ merical Simulation Settlement. Using the result extraction option in the Midas software, the points in the numerical simulation model were extracted to correspond to the monitoring points selected on-site, and the settlement values derived from the actual monitoring were compared with those from the numerical simulation (Figure 10). Differences were found between the simulated data and the actual monitoring data in terms of settlement values. Settlement values from numerical simulations are generally high compared to monitoring values. The numerical simulation of slope stability analysis uses the strength reduction method, which constantly reduces the angle of internal friction and cohesion, so that the settlement values obtained are somewhat different from the actual settlement, and the numerical simulation process is too idealized without considering the influence of other factors such as joints and faults. 


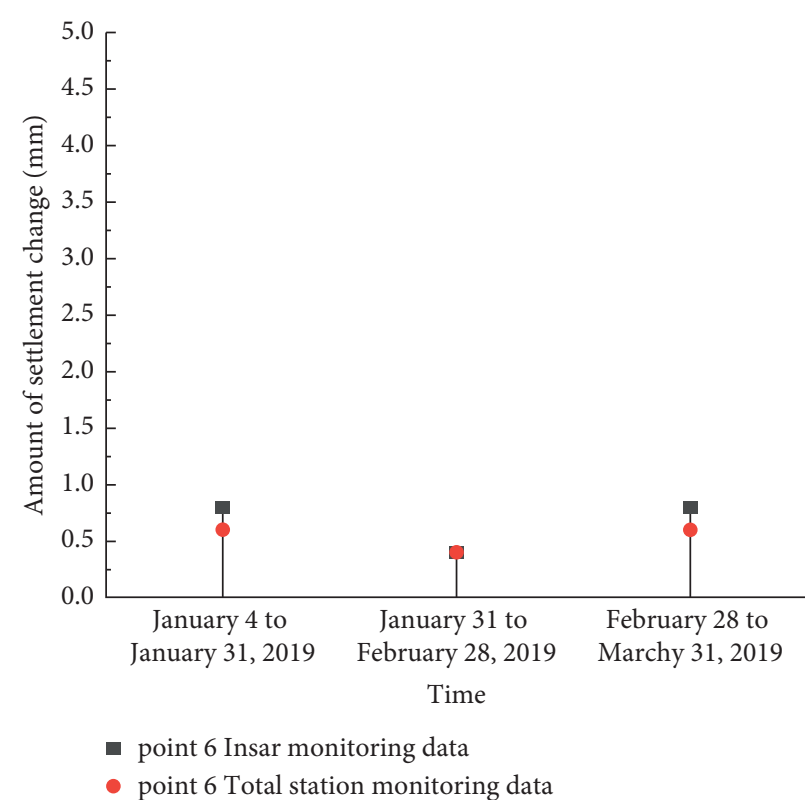

(a)

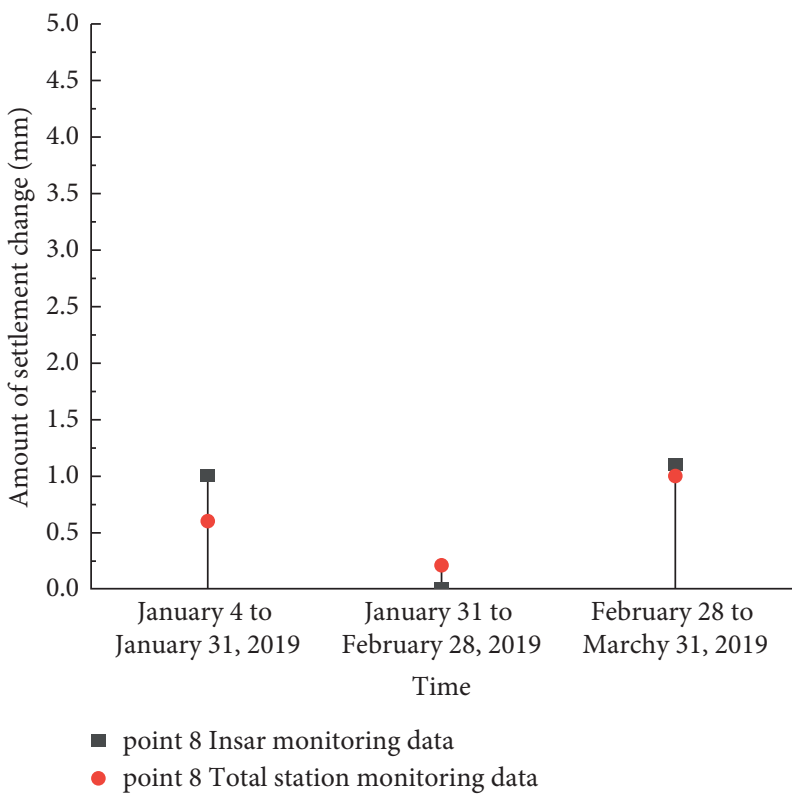

(c)

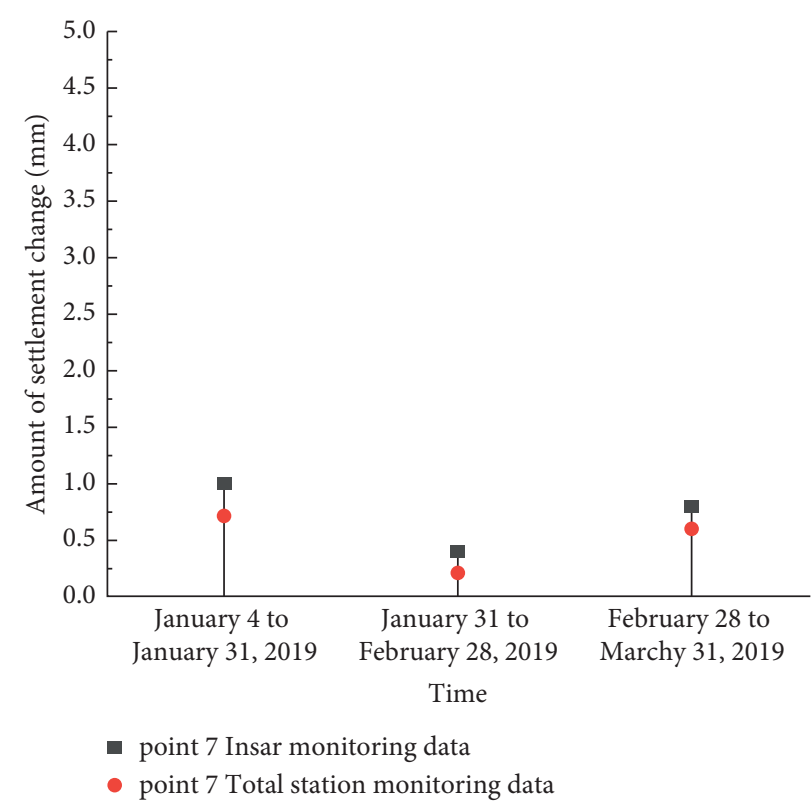

(b)

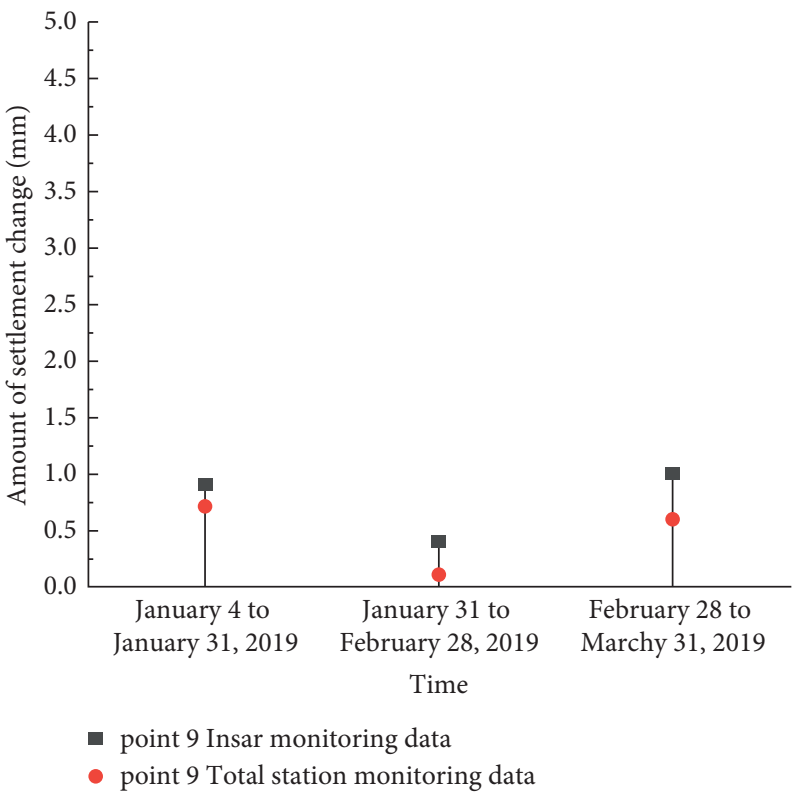

(d)

FIgURE 8: Comparison graph between total station and InSAR to monitor the amount of settlement change. (a) Monitoring point 6's sedimentation change. (b) Monitoring point 7's sedimentation change. (c) Monitoring point 8's sedimentation change. (d) Monitoring point 9's sedimentation change.

\subsubsection{Relationship between Slope Deformation and Rainfall.} In order to study the relationship between rainfall and slope deformation, open-air slope displacement data were collected by InSAR monitoring, and rainfall data were collected at the same time. Time-series analysis plots were made for monitoring points $6,7,8$, and 9 , and the results of the deformation time series with January 4, 2019, as the reference start time of surface deformation were accumulated. The cumulative settlement values of the open pit slopes obtained from the actual monitoring throughout 2019 were compared with the annual rainfall intensity of Dahongshan (Figure 11).
From the results, it can be seen that the initial slope cumulative settlement is at $5 \mathrm{~mm}$, and the graph shows that from January 2019 to May 2019, the rainfall intensity always remains at the light rainfall level (rainfall $<10 \mathrm{~mm}$ / $\mathrm{d}$ ), and the rainfall in the Dahongshan area is light or no rainfall for the whole time period during this period, and the slope cumulative settlement increases from $5 \mathrm{~mm}$ to $8 \mathrm{~mm}$. The cumulative sedimentation is more stable, showing an increasing trend but with smaller growth values. The slope is in a stable state under light and no rainfall conditions. Rainfall of medium intensity $(10 \mathrm{~mm} /$ 


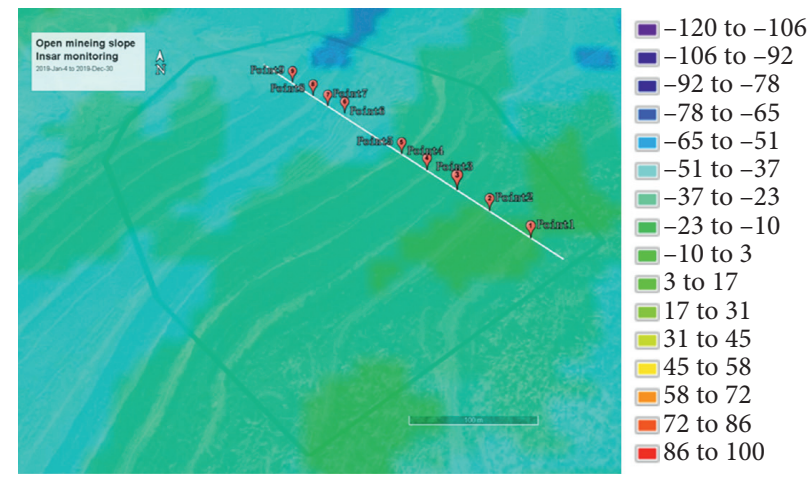

FIGURE 9: InSAR monitoring sedimentation colour chart.

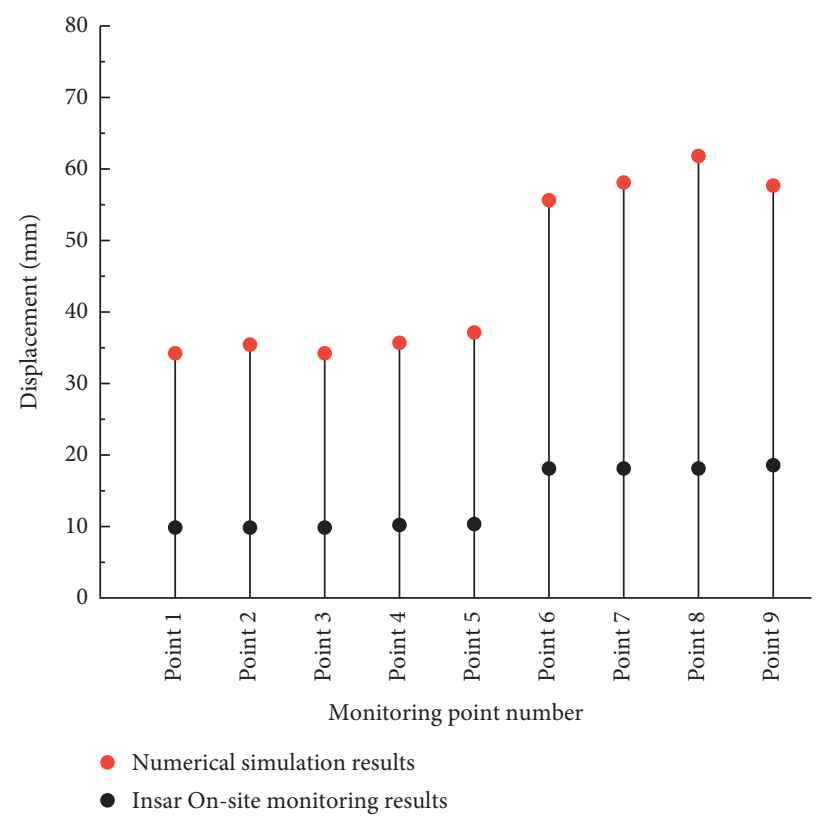

FIGURE 10: Comparison of displacement measurement results with numerical calculation results.

$\mathrm{d} \leq$ rainfall $\leq 25 \mathrm{~mm} / \mathrm{d}$ ) occurred at the end of May, but the rainfall intensity was too low to cause significant slope subsidence. The study area entered the rainy season starting in June 2019. Rainfall increased abruptly throughout June, with heavy rainfall $(100 \mathrm{~mm} /$ $\mathrm{d} \leq$ rainfall $\leq 250 \mathrm{~mm} / \mathrm{d}$ ) at the beginning of June, reaching a rainfall intensity of $200 \mathrm{~mm} / \mathrm{d}$. At this time, the slope was affected by rainfall and the accumulated settlement value changed irregularly, and the accumulated settlement value increased abruptly compared with the previous settlement trend. It increased from $8 \mathrm{~mm}$ to about $12 \mathrm{~mm}$ with an appreciation of $4 \mathrm{~mm}$, and its cumulative slope settlement value in one month exceeded the cumulative settlement value in the previous 5 months. In the middle of June, the rainfall gradually decreased and the influence of weaker rainfall intensity on slope settlement weakened, and the amount of slope settlement reverted to a stable state. Later in July, heavy rainfall also occurred in August, and its effect pattern on slope settlement was consistent with that of June. After the end of the rainy season, the accumulated slope settlement in the study area is in a stable state again, showing a trend of gradual increase without sudden increase in settlement value. From the overall data, there is a high correlation between slope deformation and rainfall.

In general, rainfall has a large impact on the stability of slopes, but the slopes in this study area remain. The monitoring frequency of the slope in the rainy season should be strengthened in the future slope monitoring work. This paper analyzes the stability of the slope of the Dahongshan iron ore open pit based on Midas/GTS numerical simulation software combined with InSAR satellite monitoring and draws the following conclusions. 


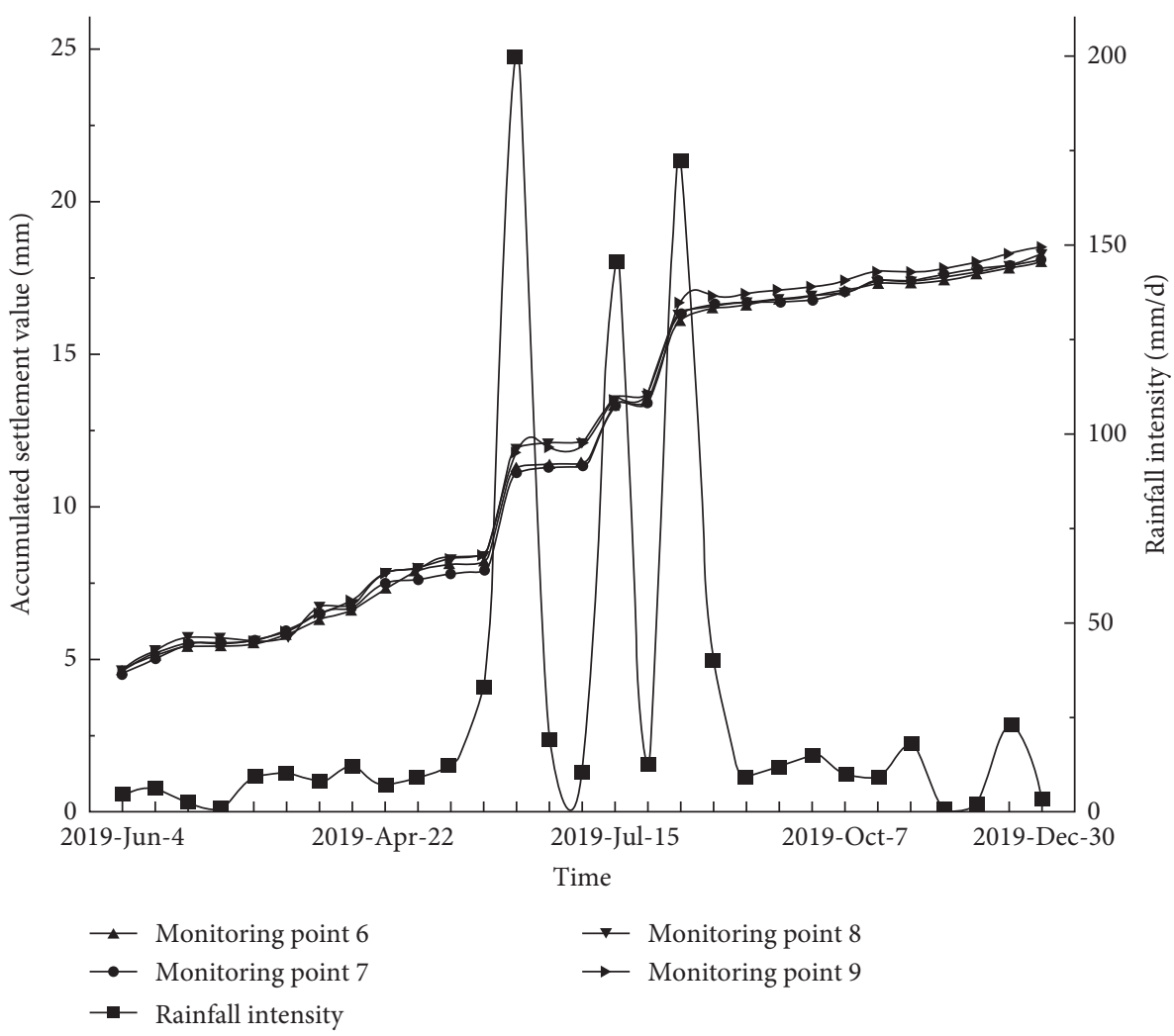

Figure 11: Plot of cumulative subsidence versus rainfall intensity.

\section{Conclusion}

Fusion technology of InSAR monitoring and Midas/GTS were used to analyze the slope stability of Dahongshan iron ore open pit, and the following conclusions were obtained.

(1) By using Midas/GTS numerical simulation and InSAR monitoring, the settlement deformation areas derived from both remain consistent, and the location of the larger settlement deformation relative to the entire study area is at platforms 895 to 1030 of the slope, and the stratum in this section of the platform is gray-green hornblende sodic lava, whose rock mechanical properties are relatively low, so the settlement at the foot of the slope is larger.

(2) Observing the cumulative value of surface settlement and the change of rainfall intensity in the study area by InSAR monitoring for a whole year, the cumulative value of slope settlement was not greatly affected when the rainfall intensity was moderate or below, and the value of settlement increased slowly with time. When heavy rainfall occurs, the cumulative value of settlement increases abruptly with time. The cumulative settlement value of the slope only changes $3 \mathrm{~mm}$ in 5 months during the nonrainy season and reaches $4 \mathrm{~mm}$ in 1 month during the rainy season. From the results of the study, there is a high correlation between heavy rainfall and the settlement of the slope.
(3) The safety coefficients of the open pit slopes derived from the numerical simulations all meet the specification requirements, and there is no obvious area of large deformation on the open pit slopes on the surface of InSAR monitoring data, and the annual accumulated settlement is $18.4 \mathrm{~mm}$. From the results, it can be seen that the analysis of the stability of the open pit slopes can be achieved by using numerical simulations combined with InSAR monitoring.

\section{Data Availability}

The datasets used and/or analyzed during the current study are available from the corresponding author upon reasonable request.

\section{Conflicts of Interest}

The authors declare that they have no conflicts of interest.

\section{Acknowledgments}

This study was supported by the Yunnan Provincial Social Development Special Key Research and Development Project (202003AC100002) (Production process and disaster evolution safety monitoring and early warning technology research), National Natural Science Foundation of China (52174114), and Muhammad Asif Khan Academician Workstation of Yunnan Province (202105AF150076). 


\section{References}

[1] M. Cała, K. Cyran, J. Jakóbczyk, and M. Kowalski, "The challenges of open-pit mining in the vicinity of the salt dome (bld," Energies, vol. 13, no. 8, p. 1913, 2020.

[2] N. F. Nizametdinov, R. F. Nizametdinova, A. A. Nagibin, and A. R. Estaeva, "Slope stability in open pit mines in clayey rock mass," Journal of Mining Science, vol. 56, no. 2, pp. 196-202, 2020.

[3] F. Liu, Q. Cai, W. Zhou et al., "Experimental study on the rainfall infiltration rule in the dump slope of surface mines," Journal of China Coal Society, vol. 40, no. 7, pp. 1534-1540, 2015.

[4] T. Han, J. Li, and X. Kang, "Stability analysis of high slope of jointed open-pit mine under rainfall conditions," Science Technology and Engineering, vol. 19, no. 19, pp. 75-80, 2019.

[5] H. R. Mohammadi Azizabadi, H. Mansouri, O. Fouché, and O. Fouché, "Coupling of two methods, waveform superposition and numerical, to model blast vibration effect on slope stability in jointed rock masses," Computers and Geotechnics, vol. 61, pp. 42-49, 2014.

[6] T.-h. Yang, W.-h. Shi, P.-t. Wang, H.-l. Liu, Q.-1. Yu, and Y. Li, "Numerical simulation on slope stability analysis considering anisotropic properties of layered fractured rocks: a case study," Arabian Journal of Geosciences, vol. 8, no. 8, pp. 5413-5421, 2015.

[7] B. Azarfar, S. Ahmadvand, J. Sattarvand, and B. Abbasi, "Stability analysis of rock structure in large slopes and openpit mine: numerical and experimental fault modeling," Rock Mechanics and Rock Engineering, vol. 52, no. 12, pp. 48894905, 2019.

[8] M. Cała, M. Kowalski, and A. Stopkowicz, "The three-dimensional (3D) numerical stability analysis of hyttemalmen open-pit," Archives of Mining Sciences, vol. 59, no. 3, pp. 609-620, 2014.

[9] N. Bar, M. Kostadinovski, M. Tucker et al., "Rapid and robust slope failure appraisal using aerial photogrammetry and 3D slope stability models," International Journal of Mining Science and Technology, vol. 30, no. 5, pp. 651-658, 2020.

[10] S. Bastola, M. Cai, and B. Damjanac, "Slope stability assessment of an open pit using lattice-spring-based synthetic rock mass (LS-SRM) modeling approach," Journal of Rock Mechanics and Geotechnical Engineering, vol. 12, no. 5, pp. 927-942, 2020.

[11] M. Morales, K. K. Panthi, and K. Botsialas, "Slope stability assessment of an open pit mine using three-dimensional rock mass modeling," Bulletin of Engineering Geology and the Environment, vol. 78, no. 2, pp. 1249-1264, 2019.

[12] J. Huang, T. Duan, Y. Lei, and M. Hasanipanah, "Finite element modeling for the antivibration pavement used to improve the slope stability of the open-pit mine," Shock and Vibration, vol. 2020, pp. 1-11, Article ID 6650780, 2020.

[13] Z. Chen, B. Yu, J. Hu et al., "Stability analysis of over sieze open-pit slope based on numerical simulation using Flac3D," Mining and Metallurgy, vol. 22, no. 3, pp. 1-6, 2013.

[14] P. Yu, "Effect of rainfall infiltration on slope stability of open pit mine," Chemical Minerals and Processing, vol. 2, pp. 5-7, 2019.

[15] F. DongZ. Guo et al., "Analysis of dynamic instability response characteristics of gently inclined slope under earthquake," Chemical Minerals and Processing, no. 7, pp. 47-51, 2019.

[16] S. Srikrishnan, J. L. Porathur, and H. Agarwal, "Impact of earthquake on mining slopes-a numerical approach," Arabian Journal of Geosciences, vol. 7, no. 12, pp. 5193-5208, 2014.
[17] X. Liu, G. Ziyu, L. Wang, and H. Gao, Analysis on the slope stability of Fushun West Open-Pit Mine under superimposed action of rainfall, mine and earthquake," Chinese Journal of Geological Hazard and Control, vol. 32, no. 4, pp. 40-46, 2021.

[18] L. Zhao and G. You, "Rainfall affected stability analysis of Maddingley Brown Coal eastern batter using Plaxis 3D," Arabian Journal of Geosciences, vol. 13, no. 20, p. 1071, 2020.

[19] W. ZhuM. Ren et al., "Prediciton and early warning of mining-induced disasters based on combined in-situ monitoring and numerical simulation," Metal Mine, no. 1, pp. 151-162, 2020.

[20] Xu HeKeG. Li et al., "Slope stability analysis of a phosphate open-pit mine," Mining Research and Development, vol. 41, no. 09, pp. 25-28, 2020.

[21] X. Yang and D. Hou, "Research on correlations between slope stability and rainfall of high steep slope on Nanfen open-pit iron ore," Chinese Journal of Rock Mechanics and Engineering, no. 35, pp. 3232-3240, 2016.

[22] F. Zhang, T. Yang, L. Li, Z. Wang, and P. Xiao, "Cooperative monitoring and numerical investigation on the stability of the south slope of the Fushun west open-pit mine," Bulletin of Engineering Geology and the Environment, vol. 78, no. 4, pp. 2409-2429, 2018.

[23] F.. Zhang, T.. Yang, L. Li, J. Bu, T. Wang, and P. Xiao, "Assessment of the rock slope stability of Fushun West openpit mine," Arabian Journal of Geosciences, vol. 14, no. 15, 2021.

[24] Z. Sertabipoğlu, Ü. Özer, and H. Tunçdemir, "Assessment of slope instability with effects of critical displacement by using InSAR and FEM," Arabian Journal of Geosciences, vol. 13, no. 4, p. 177, 2020.

[25] Z. Li, Z. Tao, Y. Jiang, Q. Lv, F. Darve, and M. He, "Real-time monitoring and FEMLIP simulation of a rainfall-induced rockslide," Natural Hazards and Earth System Sciences, vol. 19, no. 1, pp. 153-168, 2019.

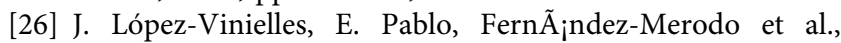
"Remote analysis of an open-pit slope failure: Las Cruces case study, Spain," Landslides, vol. 17, no. 9, pp. 2173-2188, 2020.

[27] K. Zhang, X. Yang, X. Cui, Y. Wang, and Z. Tao, "Numerical simulation analysis of NPR anchorage monitoring of bedding rock landslide in open-pit mine," Advances in Civil Engineering, vol. 2020, pp. 1-17, Article ID 8241509, 2020.

[28] Y. Zhu and W. Wang, "Application of GPS technique in the slope safety monitoring of opencast uranium mine based on VBA," Metal Mine, no. 1, pp. 136-138, 2011.

[29] T. Carlà, E. Intrieri, F. Raspini et al., "Perspectives on the prediction of catastrophic slope failures from satellite InSAR," Scientific Reports, vol. 9, no. 1, p. 14137, 2019.

[30] I. N. S. Parwata, S. Nakashima, N. Shimizu, and T. Osawa, "Effect of digital elevation models on monitoring slope displacements in open-pit mine by differential interferometry synthetic aperture radar," Journal of Rock Mechanics and Geotechnical Engineering, vol. 12, no. 5, pp. 1001-1013, 2020.

[31] N. Bar and R. Dixon, "Unveiling unknowns: practical application of InSAR for slope performance monitoring and risk management across multiple surface mines," Engineering Geology, vol. 293, p. 106326, 2021. 